\title{
POLÍTICA EDUCACIONAL DE DESCARTE DE LIXO ELETRÔNICO COMO MEDIDA DE COMBATE AO CRIME AMBIENTAL
}

\author{
Maria Fernanda Soares Macedo* \\ Evandro Fabiani Capano**
}

SUMÁRIO: Introdução; 2 Direito ambiental: o antropocentrismo e o biocentrismo; 3 A sociedade informatizada e a produção de lixo eletrônico; 4 Descarte incorreto do lixo eletrônico; 4.1 Condutas dolosas, culposas e o crime ambiental; 5 Políticas públicas educacionais ambientais, sustentabilidade e preservação da biota; 6 Considerações finais; Referências.

RESUMO: O descarte inadequado do lixo eletrônico configura crime ambiental e acarreta diversas consequências danosas tanto para a saúde humana quanto para o meio ambiente. Tendo em vista que se trata de demanda decorrente de comportamento presente na sociedade moderna cada vez mais equipada com aparelhos eletroeletrônicos (que são considerados desatualizados com grande velocidade e este é um dos motivos de sua rápida substituição), o principal objetivo do presente estudo é discorrer sobre a necessidade de consolidação de políticas públicas educacionais destinadas ao correto descarte do lixo eletrônico. Os objetivos parciais, por sua vez, consistem na identificação de fatores que dificultam o acesso das pessoas ao descarte eletrônico ecologicamente correto, além da propositura de possíveis soluções para a superação destas barreiras. Para o desenvolvimento das referidas pesquisas foi adotado o método de revisão bibliográfica.

PALAVRAS-CHAVE: Dignidade humana; Educação ambiental; Lixo eletrônico; Crime ambiental.

\section{EDUCATIONAL POLICY OF DISCARDING ELECTRONIC WASTES AS A WAY OF FIGHTING ENVIRONMENTAL CRIME}

ABSTRACT: Improper discarding of electronic wastes is an environmental crime and brings serious consequences to human health and to the environment. Since it is a demand triggered by current behavior in modern society fully equipped with elec-

\footnotetext{
Advogada. Docente Universitária; Doutoranda e Mestra em Direito Político e Econômico pela Universidade Presbiteriana Mackenzie, São Paulo, Brasil. E-mail: mariafernanda_soaresmacedo@yahoo.com.br

** Doutor em Direito do Estado pela Universidade de São Paulo e Doutor em Direito pela Universidad de Salamanca - Espanha, em programa de dupla titulação, com Defesa Pública de Suficiência Investigatória na Espanha e Defesa Pública de Tese em São Paulo; Docente na Graduação e da Pós-Graduação Lato sensu da Faculdade de Direito da Universidade Presbiteriana Mackenzie, São Paulo, Brasil.
} 
tro-electronic devices (easily outdated and rapidly replaced), current study discusses the need for consolidating education public policies for the adequate disposal of ewastes. Partial aims are the identification of factors that make difficult access to ecologically correct disposal of e-wastes and possible solutions for the overcoming of barriers. Bibliographical review has been adopted as a method for current research.

KEY WORDS: Human dignity; Environmental education; E-waste; Environmental crime.

\section{POLÍTICA EDUCACIONAL DE DESECHO DE BASURA ELECTRÓNICA COMO MEDIDA DE COMBATE AL CRIMEN AMBIENTAL}

RESUMEN: O descarte inadecuado del desecho electrónico configura crimen ambiental y resulta diversas consecuencias dañosas tanto a la salud humana como para el medio ambiente. Teniendo en vista que se trata de demanda derivado de comportamiento presente en la sociedad moderna cada vez más equipada con aparatos electro electrónicos (que son considerados obsoletos con gran velocidad y este es uno de los motivos de su rápida substitución), el principal objetivo del presente estudio es explayarse sobre la necesidad de consolidación de políticas públicas educacionales destinadas al correcto descarte de la basura electrónica. Los objetivos parciales, por su vez, consisten en la identificación de factores que dificultan el acceso de las personas al descarte electrónico ecológicamente correcto, además de la proposición de posibles soluciones para la superación de estos obstáculos. Para el desarrollo de las referidas investigaciones se adoptó el método de revisión bibliográfica.

PALABRAS CLAVE: Dignidad humana; Educación ambiental; Basura electrónica; Crimen ambiental.

"A base de toda a sustentabilidade é o desenvolvimento humano que deve contemplar um melhor relacionamento do homem com os semelhantes e a Natureza."

Nagib Anderáos Neto. 


\section{INTRODUÇÃO}

O direito é a principal ferramenta adotada pelos homens para a organização da sociedade. Dentre suas funções, apresenta parâmetros que devem ser seguidos e respeitados por todos os cidadãos, bem como as normas referentes a condutas permitidas e proibidas, com a previsão expressa das respectivas consequências decorrentes da prática dos atos infracionais. Trata-se de medida fundamental para a viabilidade e a segurança das relações intersubjetivas, além da tutela adequada para a proteção dos direitos e interesses individuais, difusos e coletivos.

Neste sentido merece destaque o pensamento de Norberto Bobbio ${ }^{03}$, que se dedicou a analisar as diversas demandas da sociedade e os sujeitos tutelados, consagrando o termo "gerações de direitos" em sua obra "A Era dos Direitos". Em apertada síntese, os denominados direitos de primeira geração têm por objetivo limitarem a atuação estatal e referem-se aos direitos fundamentais do homem, a preservação do direito à vida, liberdade e a igualdade. A geração subsequente demanda uma atuação ativa do Estado, para que os direitos humanos relacionados à vida digna, como a educação, o trabalho, a moradia e a saúde sejam garantidos. A terceira geração de direitos abrange questões relacionadas à coletividade, em especial buscando a proteção do consumidor e do meio ambiente e tendo por escopo a preservação dos recursos naturais. Por fim, cabe à geração posterior o cuidado com questões relacionadas à globalização política, ao pluralismo, à informação e à engenharia genética. Indubitavelmente a previsão normativa dos referidos direitos é um grande avanço para a proteção da vida humana, mas as discussões devem abranger também os mecanismos pelos quais eles serão efetivados. É necessário destacar também a função coercitiva do direito, que deve ser aplicada quando as normas são violadas. Ao discorrer sobre o ordenamento jurídico na obra "Teoria da Norma Jurídica", Norberto Bobbio $^{04}$ apresenta as seguintes lições:

Uma norma prescreve o que deve ser. Mas aquilo que deve ser não corresponde sempre ao que é. Se a ação real não corresponde à ação prescrita, afirma-se que a norma foi violada. É da natureza de toda a prescrição ser violada, enquanto exprime não o que é, mas o que deve ser. À violação, dá-se o nome de ilícito. O ilícito consiste em uma ação quando a norma é um imperativo negativo e em uma omis-

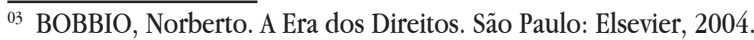

${ }^{04}$ BOBBIO, Norberto. Teoria da norma jurídica. Tradução: Fernando Pavan Baptista e Ariani Bueno Sudatti. Bauru, SP: EDIPRO: 4 ed. Revista, 2008. p. 152-153. 
são quando a norma é um imperativo positivo. No primeiro caso, afirma-se que a norma não foi observada, no segundo, que não foi executada. [...] A ação que é cumprida sobre a conduta não conforme para anulá-la, ou pelo menos para eliminar suas consequências danosas, é precisamente aquilo que se chama de sanção. A sanção pode ser definida, por este ponto de vista, como o expediente através do qual se busca, em um sistema normativo, salvaguardar a lei da erosão das ações contrárias.

As discussões referentes ao principal objetivo do presente ensaio - a necessidade de políticas educacionais destinadas ao correto descarte de lixo eletrônico - devem ser conjugadas com o estudo acerca das consequências juridicamente previstas para as situações de descumprimento das normas.

Inicialmente serão apresentadas considerações acerca do direito ambiental em suas visões antropocêntrica e biocêntrica, para que possam ser abordadas as diversas formas pelas quais são analisadas as relações estabelecidas entre o homem e o meio ambiente. Em seguida serão expostos aspectos de divergência entre o tema - direito ambiental (localizado na Constituição Federal de 1988, CF/88 e em plano infraconstitucional) e as dificuldades de sua preservação e conservação frente ao intenso consumo e descarte inadequado de aparelhos eletrônicos, característicos da sociedade informatizada. Neste ponto, serão trazidas questões referentes aos objetos parciais de estudo, pertinentes à análise da necessidade de políticas educacionais de descarte correto de lixo eletrônico, além de medidas que esclareçam que esta conduta configura a prática de crime ambiental. Por fim, espera-se apresentar sugestões que tenham o condão de garantirem tanto a sustentabilidade ambiental quanto a preservação e conservação da biota.

\section{DIREITO AMBIENTAL: O ANTROPOCENTRISMO E O BIOCENTRISMO}

A proteção do meio ambiente é vital para a sobrevivência das espécies. Trata-se de condição profundamente relacionada à proteção da dignidade humana e à preservação da biota ${ }^{05}$. $\mathrm{O}$ art. $225 \mathrm{da} \mathrm{CF} / 88^{06}$ consagra esta tutela constitucional.

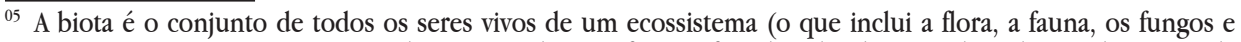
outros organismos). Em seu sentido mais amplo, significa a esfera da vida, abrangendo todos os elementos da biosfera (litosfera, hidrosfera, criosfera e atmosfera).

${ }^{06}$ BRASIL. Constituição (1998). Constituição da República Federativa do Brasil. Brasília, DF: Senado Federal. Centro Gráfico, 1998. 292p.
} 
Todos têm direito ao meio ambiente ecologicamente equilibrado, bem de uso comum do povo e essencial à sadia qualidade de vida, impondo-se ao Poder Público e à coletividade o dever de defendê-lo e preservá-lo para as presentes e futuras gerações. $\S$ $1^{\circ}$ Para assegurar a efetividade desse direito, incumbe ao Poder Público: I - preservar e restaurar os processos ecológicos essenciais e prover o manejo ecológico das espécies e ecossistemas; VI - promover a educação ambiental em todos os níveis de ensino e a conscientização pública para a preservação do meio ambiente (grifos nossos).

Este cunho de proteção transcendental e de responsabilidade abrangente se reflete em diversos diplomas infraconstitucionais ${ }^{07}$. A lei $n^{0}$. 9.605/98 ${ }^{08}$ dispõe sobre as sanções penais e administrativas derivadas de condutas e atividades lesivas ao meio ambiente. Cabe à lei $\mathrm{n}^{\mathrm{o}}$. 8171/9109 cuidar da lei da Política Agrícola, colocando a proteção do meio ambiente entre seus objetivos e como um de seus instrumentos, definindo ainda que o poder público deve disciplinar e fiscalizar o uso racional do solo, da água, da fauna e da flora; realizar zoneamentos agroecológicos para ordenar a ocupação de diversas atividades produtivas, desenvolver programas de educação ambiental, além de fomentar a produção de mudas de espécies nativas. Em agosto de 2010 foi promulgada a lei $\mathrm{n}^{\mathrm{0}}$. $12.305^{10}$, instituindo a Política Nacional de Resíduos Sólidos (PNRS). Esta lei (também conhecida como lei do lixo eletrônico) reúne o conjunto de princípios, objetivos, instrumentos, diretrizes, metas e ações adotadas pelo governo federal, isoladamente ou em regime de cooperação com Estados, Distrito Federal, municípios e particulares, com vistas à gestão integrada e ao gerenciamento ambientalmente adequado dos resíduos sólidos. Em seu art. $6^{\circ}$, a lei $n^{\circ}$.

\footnotetext{
${ }^{07}$ Antes mesmo da Constituição Federal de 1988 já existia, no Brasil, tímida movimentação na busca pela proteção ambiental. A Lei Federal no 6.938, de 31 de agosto de 1981, dispõe sobre a Política Nacional do Meio Ambiente e, em seu art. $2^{\circ}$, prevê: "A Política Nacional do Meio Ambiente tem por objetivo a preservação, melhoria e recuperação da qualidade ambiental propícia à vida, visando assegurar, no País, condiçóes ao desenvolvimento socioeconômico, aos interesses da segurança nacional e à proteção da dignidade da vida humana, atendidos os seguintes princípios: I - ação governamental na manutenção do equilíbrio ecológico, considerando o meio ambiente como um patrimônio público a ser necessariamente assegurado e protegido, tendo em vista o uso coletivo; II - racionalização do uso do solo, do subsolo, da água e do ar; III - planejamento e fiscalização do uso dos recursos ambientais; IV - proteção dos ecossistemas, com a preservação de áreas representativas; $\mathrm{V}$ - controle e zoneamento das atividades potencial ou efetivamente poluidoras; VI - incentivos ao estudo e à pesquisa de tecnologias orientadas para o uso racional e a proteção dos recursos ambientais; VII - acompanhamento do estado da qualidade ambiental; VIII - recuperação de áreas degradadas; IX - proteção de áreas ameaçadas de degradação; $\mathrm{X}$ - educação ambiental a todos os níveis de ensino, inclusive a educação da comunidade, objetivando capacitá-la para participação ativa na defesa do meio ambiente"

${ }^{08}$ BRASIL. Lei ${ }^{0}$. 9.605, de 12 de fevereiro de 1998: dispõe sobre as sanções penais e administrativas derivadas de condutas e atividades lesivas ao meio ambiente.

${ }^{09}$ BRASIL. Lei $\mathrm{n}^{\circ} .8 .171$, de 17 de janeiro de 1991: dispõe sobre a política agrícola.

${ }^{10}$ BRASIL. Lei $\mathrm{n}^{\mathrm{o}} .12 .305$, de 02 de agosto de 2010: institui a Política Nacional de Resíduos Sólidos; altera a Lei no 9.605 , de 12 de fevereiro de 1998.
} 
12.305/10 apresenta seus princípios e objetivos, dentre os quais: a visão sistêmica, na gestão dos resíduos sólidos, que considere as variáveis ambiental, social, cultural, econômica, tecnológica e de saúde pública; o desenvolvimento sustentável; a ecoeficiência, mediante a compatibilização entre o fornecimento, a preços competitivos, de bens e serviços qualificados que satisfaçam as necessidades humanas e tragam qualidade de vida e a redução do impacto ambiental e do consumo de recursos naturais a um nível, no mínimo, equivalente à capacidade de sustentação estimada do planeta; a cooperação entre as diferentes esferas do poder público, o setor empresarial e demais segmentos da sociedade; a responsabilidade compartilhada pelo ciclo de vida dos produtos; o reconhecimento do resíduo sólido reutilizável e reciclável como um bem econômico e de valor social, gerador de trabalho e renda e promotor de cidadania. Prevê o art. 33, VI, da referida legislação que

São obrigados a estruturar e implementar sistemas de logística reversa, mediante retorno dos produtos após o uso pelo consumidor, de forma independente do serviço público de limpeza urbana e de manejo dos resíduos sólidos, os fabricantes, importadores, distribuidores e comerciantes de: produtos eletroeletrônicos e seus componentes.

Em São Paulo, a temática - descarte correto do lixo eletrônico - foi objeto de debates, tendo resultado na lei estadual $\mathrm{n}^{0}$. 13.576/09 ${ }^{11}$, que prevê em seu art. $1^{\mathrm{o}}$ que os produtos e os componentes eletroeletrônicos considerados lixo tecnológico devem receber destinação final adequada que não provoque danos ao meio ambiente nem à sociedade. Estabelece também que é solidária a responsabilidade pela destinação final entre as empresas que produzam, comercializem ou importem produtos e componentes eletroeletrônicos. A análise sobre o direito ambiental comporta diversas abordagens. Nos dizeres de Milton $^{12}$

Não existe uma "ecologia humana" única. Pelo contrário, podemos notar "uma multitude de distintas ecologias, cada uma das quais, incluindo a que pertence à ciência ocidental, foi gerada por uma experiência distinta de mundo, cada uma das quais encarnando por si mesma seu próprio e único modo de compreendê-lo.

Enquanto o já superado pensamento antropocêntrico insere o homem como o centro do Universo, relegando a preservação ambiental para segundo plano,

\footnotetext{
${ }^{11}$ SÃO PAULO. Lei estadual $\mathrm{n}^{\circ}$. 13.576, de 06 de julho de 2009: Institui normas e procedimentos para a reciclagem, gerenciamento e destinação final de lixo tecnológico.

${ }^{12}$ MILTON, Kay. Ecologias: antropologia, cultura y entorno apud WALDMAN, Maurício. Meio ambiente \& antropologia. São Paulo: Editora Senac São Paulo, 2006, p. 41.
} 
o biocentrismo ${ }^{13}$, corrente doutrinária contemporânea, elege como plano principal de discussão a proteção do equilíbrio dos ecossistemas e do meio ambiente natural. Ulrich Beck ${ }^{14}$ esclarece:

Não se pode mais pensar na natureza de forma apartada da sociedade e vice-versa, pois os problemas do meio ambiente não são problemas do entorno, mas em sua gênesis e em suas consequências, problemas sociais, do ser humano, de sua história, de suas condições de vida, de sua concepção de mundo e da realidade, de seu ordenamento econômico, cultural e político.

As ações desenfreadas dos homens, decorrentes de suas necessidades ilimitadas são a causa de inúmeros prejuízos como a contaminação, poluição e escassez (ou eliminação) de recursos ambientais, além de desastres ecológicos, como alguns dos casos ocorridos no Brasil:

- caso Césio 137, grave episódio de contaminação radioativa, ocorrido em setembro de 1987, em Goiânia' ${ }^{15}$. Pela extensão dos danos, foi classificado como nível 5 na escala internacional de acidentes nucleares $\left(\right.$ INES $\left.^{16}\right)$ :

\footnotetext{
${ }^{13}$ A Lei da Política Nacional do Meio Ambiente (Lei n ${ }^{\circ}$. 6938/81) adota a visão biocêntrica: "Art $2^{\circ}$ - A Política Nacional do Meio Ambiente tem por objetivo a preservação, melhoria e recuperação da qualidade ambiental propícia à vida, visando assegurar, no País, condiçóes ao desenvolvimento socioeconômico, aos interesses da segurança nacional e à proteção da dignidade da vida humana. Art $3^{\circ}$ - Para os fins previstos nesta Lei, entende-se por: I - meio ambiente, o conjunto de condições, leis, influências e interações de ordem física, química e biológica, que permite, abriga e rege a vida em todas as suas formas".

${ }^{14}$ BECK, Ulrich. La sociedad Del riesgo: hacia una nueva modernidad. Barcelona, Buenos Aires. México: Paidós, 1998, p.80.

${ }^{15}$ GOIANIA. Secretaria de Estado de Gestão e Planejamento. Césio 137 a história do acidente radioativo em Goiânia. 2012. Disponível em: http://www.cesio137goiania.go.gov.br/index.php?idEditoria=3823. Acesso em: 22 jan. 2017.

${ }^{16}$ INES. The International Nuclear and Radiological Event Scale. International Conference: Goiânia, ten years later. Out. 1997. Disponível em: http://www-ns.iaea.org/meetings/rw-summaries/goiania-1997.asp?s $=10 \& l=80$. Acesso em: 22 jan. 2017. A Agência Internacional de Energia Atômica (AIEA) introduziu a Escala Internacional de Acidentes Nucleares e Radiológicos (em inglês, International Nuclear Event Scale - INES), que é composta por sete níveis, em 1990. O primeiro nível é intitulado como anomalia (anomaly) e não causa prejuízos nem riscos de prejuízos nucleares e ambientais. O segundo nível, nomeado como incidente (incident) ocorre quando os trabalhadores se expõem além do limite legal anual de radiação. O terceiro nível, o incidente grave (serious incident) corresponde a situações em que os trabalhadores ficam expostos a até dez vezes o limite anual de substâncias nocivas, o que lhes pode causar diversos ferimentos não letais, como as queimaduras. No quarto nível - acidente com consequências locais (accident with local consequences), a liberação de material radioativo, em pequena quantidade, é a causa de pelo menos uma morte. O quinto nível por sua vez versa sobre acidentes com consequências de longo alcance (accident with wider consequencies), em que os danos no núcleo do reator acarretam graves consequências para as pessoas e meio ambiente. No sexto nível, intitulado como acidente grave (serious accident), é passível de exigência a adoção de medidas remediadoras em decorrência dos riscos acarretados pelo material tóxico liberado. Por fim, o sétimo nível, conhecido como acidente mais severo (major accident), é caracterizado pela exigência de medidas remediadoras em decorrência da liberação e longo alcance de material altamente nocivo.
} 
Com a violação do equipamento, foram espalhados no meio ambiente vários fragmentos de $137 \mathrm{Cs}$, na forma de um sólido de cor azul, sem brilho durante o dia, porém no escuro, emitia brilho forte e magnetizante. Isto provocou a contaminação de diversos locais, especificamente naqueles onde houve manipulação do material e para onde foram levadas as várias partes do aparelho de radioterapia. Por conter chumbo e metal, materiais de algum valor financeiro, a fonte foi vendida para um depósito de ferro-velho,onde também se comercializava materiais recicláveis. $\mathrm{O}$ dono deste estabelecimento a repassou a outros dois depósitos, além de distribuir os fragmentos do material radioativo a parentes e amigos. Estes, por suas vezes, também levaram os fragmentos para suas casas. Dentre as pessoas que tiveram contato com o material radioativo - tipo por contato direto na pele (contaminação externa), ou por inalação, ingestão, ou absorção por penetração através de microlesões da pele (contaminação interna) e por irradiação - algumas apresentaram, desde os primeiros dias, náuseas, vômitos, diarreia, tonturas e lesões do tipo queimadura na pele. Várias delas buscaram assistência médica em hospitais locais. A esposa do dono do depósito de ferro-velho, suspeitando que aquele material tivesse relação com o mal-estar que se abateu sobre sua família, levou a peça para a Divisão de Vigilância Sanitária da Secretaria Estadual de Saúde, onde finalmente o material foi identificado como radioativo. Devido às características do acidente de Goiânia, as vias potenciais de exposição da população à radiação foram: inalação de material ressuspenso, ingestão de frutas, verduras e animais domésticos e irradiação externa devido ao material depositado no ambiente.

\section{- caso incêndio no Terminal Químico de Aratu/Tequimar, do Grupo Ultracar- go, ocorrido em abril de 2015, no Terminal Alemoa (localizado em Santos) ${ }^{17}$ :}

A Tequimar foi multada por: lançar efluentes líquidos no estuário de Santos, em manguezais e na lagoa contígua ao terminal, e emitir efluentes gasosos na atmosfera; colocar em risco a segurança das comunidades próximas, dos funcionários e de outras instalações localizadas na mesma zona industrial; ocasionar incômodos significativos ao bem estar da população; e provocar a mortandade de milhares de peixes, de várias espécies, no estuário e no rio Casqueiro, prejudicando a pesca na região. A penalidade se baseou nos artigos 61 e 62 do decreto federal 6514/08, que regulamenta a Lei de Crimes Ambientais (Lei 9.605/98).

- caso rompimento da barragem da Samarco em Mariana (MG), ocorrido em novembro de $2015^{18}$ :

${ }_{17}$ SAP. Sistema Ambiental Paulista. Governo do Estado de São Paulo. Cetesb multa Ultracargo em R\$ 22,5 milhões pelo incêndio em Santos. 14 abril 2015. Disponível em: http://www.ambiente.sp.gov.br/2015/04/15/cetesb-multa-ultracargo-em-mais-de-22-milhoes-pelo-incendio-no-terminal-da-alemoa/. Acesso em: 20 jan. 2017.

${ }^{18}$ PORTAL BRASIL. Meio ambiente. Desastre ambiental. Entenda o acidente de Mariana e suas consequências para o meio ambiente. 23 dez. 2015. Disponível em: http://www.brasil.gov.br/meio-ambiente/2015/12/entenda-o-acidente-de-mariana-e-suas-consequencias-para-o-meio-ambiente. Acesso em: 19 jan. 2016. 
$\mathrm{Na}$ tarde do dia 5 de novembro, o rompimento da barragem do Fundão, localizada na cidade histórica de Mariana (MG), foi responsável pelo lançamento no meio ambiente de 34 milhões de $\mathrm{m}^{3}$ de lama, resultantes da produção de minério de ferro pela mineradora Samarco --empresa controlada pela Vale e pela britânica BHP Billiton. Seiscentos e sessenta e três quilômetros de rios e córregos foram atingidos; 1.469 hectares de vegetação, comprometidos; 207 de 251 edificações acabaram soterradas apenas no distrito de Bento Rodrigues. Esses são apenas alguns números do impacto, ainda por ser calculado, do desastre, já considerado a maior catástrofe ambiental da história do país. A enxurrada de rejeitos rapidamente se espalhou pela região, deixou mais de 600 famílias desabrigadas e chegou até os córregos próximos. Até o momento, foram confirmadas as mortes de 17 pessoas. O aumento da turbidez da água, e não uma suposta contaminação, provocou a morte de milhares de peixes e outros animais. De acordo com o Ibama, das mais de 80 espécies de peixes apontadas como nativas antes da tragédia, 11 são classificadas como ameaçadas de extinção e 12 existiam apenas lá.

Tanto a responsabilização dos causadores dos danos supracitados quanto o embasamento normativo para que seja requerida a reparação em decorrência dos prejuízos sofridos perpassam pela esfera criminal. Ademais, é fundamental uma minuciosa avaliação e mapeamento acerca das necessidades locais e regionais para que sejam implementadas as políticas públicas adequadas, eis que a falta de planejamento urbanístico e o crescimento vertiginoso das cidades se refletem na inadequada perspectiva de atendimento às necessidades mais básicas ao ser humano, como tratamento sanitário, alimentação, moradia, saúde, abastecimento de água, serviços de coleta e destinação do lixo urbano, elementos essenciais para saúde humana. Fabíola Rodrigues e Rosana Baeninger ${ }^{19}$ esclarecem que

Nesse contexto de desigual distribuição entre recursos e necessidades, o campo disciplinar da demografia possibilita ampliar o alcance das políticas sociais. De fato, como adequar os recursos financeiros e humanos disponíveis, com eficiência e economicidade, na execução de políticas, programas e ações que visam realizar os direitos sociais (moradia, educação, saúde, trabalho, lazer, previdência) se não se conhecem as populações-alvo? Exatamente por não conhecê-las, as políticas e os gestores tratam a população de modo homogêneo, padronizado, como se não se alterassem no tempo e no espaço. Esses questionamentos nos levam a apontar, provocadoramente, que o fracasso de muitas políticas sociais, particularmente entre os muni-

\footnotetext{
${ }^{19}$ RODRIGUES, Fabíola. BAENINGER, Rosana. Dinâmica da população e políticas sociais. In. População e Cidades: subsídios para o planejamento e para as políticas sociais / Rosana Baeninger (Org.). Campinas: Núcleo de Estudos de População-Nepo/Unicamp; Brasília: UNFPA, 2010.p.27.
} 
cípios, não se devem (apenas) à falta de recursos financeiros ou de pessoal qualificado, mas sim decorrem de políticas mal desenhadas, ou seja, em cujo planejamento e formatação não se levou em conta - pelo menos não de forma adequada - a composição, o comportamento, as características e as necessidades das populações-alvo.

As preocupações com as demandas ambientais se intensificaram a partir de 1970, período marcado pela industrialização, pelo processo de urbanização descomedido e não planejado, pela contaminação e pelo consumo excessivo de recursos naturais não renováveis, além do avanço de destruição da camada de ozônio e consequentemente, do alastramento do efeito estufa. Em 1972, a Organização das Nações Unidas (ONU) apresentou a Conferência das Nações Unidas sobre o ambiente humano, em Estocolmo (Suécia). O legado da Conferência foi a elaboração e publicação dos 19 princípios norteadores da proteção ambiental, dentre os quais destacamos o $19^{\mathrm{o} 20}$ :

É indispensável um trabalho de educação em questões ambientais, visando tanto às gerações jovens como os adultos, dispensando a devida atenção ao setor das populações menos privilegiadas, para assentar as bases de uma opinião pública, bem informada e de uma conduta responsável dos indivíduos, das empresas e das comunidades, inspirada no sentido de sua responsabilidade, relativamente à proteção e melhoramento do meio ambiente, em toda a sua dimensão humana.

Além de ser importante diretriz para diversas legislações, este princípio reflete a busca pelo equilíbrio das necessidades da vida em sociedade, cada vez mais dinâmica e integrada. É muito delicada a relação entre a sociedade informatizada e proteção ao meio ambiente. Nas lições de Torres ${ }^{21}$

O maior perigo do avanço da tecnologia é seu considerável impacto ambiental. Principalmente a indústria de computadores e seus periféricos eletrônicos que constituem um dos setores industriais que proporcionalmente ao peso dos seus produtos, mais consomem recursos naturais, tanto na forma de matéria-prima, como em termos de água e energia.

Dentre os inúmeros quesitos referentes à preservação ambiental, o tema

\footnotetext{
${ }^{20}$ Organização das Nações Unidas. Declaração de Estolcomo sobre o ambiente humano. Junho de 1972. Disponível em: < http://www.silex.com.br/leis/normas/estocolmo.htm>. Acesso em: 26 de março de 2016.

${ }^{21}$ TORRES, Marco Antônio. Lixo Eletrônico: O lado sujo da tecnologia. Anexo XII, n.73, abril 2008. Disponível em: < http://www.sciencenet.com.br/>. Acesso em: 14 fev.2015.
} 
analisado versa sobre a necessidade de políticas públicas nacionais para o correto descarte de lixo eletrônico, também conhecido como Resíduos de Equipamentos Eletro Eletrônicos (REEE).

\section{A SOCIEDADE INFORMATIZADA E A PRODUÇÃO DE LIXO ELETRÔNICO}

A globalização é um importante meio de integração econômica, cultural, política, jurídica e social em âmbito internacional para os países participantes, e acarreta-lhes consequências positivas e negativas.

Entre os pontos favoráveis, é possível elencar o desenvolvimento da tecnologia, a diminuição dos custos da produção de bens, a rapidez para que seja efetuada a comunicação e para que se tome ciência das notícias dos outros países, o acesso a outras culturas e pesquisas científicas, além da circulação de bens, serviços e pessoas. É necessário, entretanto, ressaltar que muitos dos aspectos desfavoráveis estão relacionados com a temática ambiental, já que a produção industrial gera poluição das águas, do ar e do solo. Ademais, a desregrada extração de recursos naturais e o inadequado descarte dos resíduos também são altamente danosos e destrutivos. Tendo em vista que o escopo desta pesquisa versa sobre os prejuízos ambientais causados pelos resíduos de lixo eletrônico, será feita uma breve retomada acerca do desenvolvimento histórico dos equipamentos eletrônicos (com ênfase para a evolução dos computadores, já que o desenvolvimento de seu sistema operacional é um importante embasamento para a estruturação dos sistemas de outros aparelhos), para que então se possa discorrer sobre a relação entre a produção deste material, a necessidade de seu descarte e a poluição ambiental decorrente da inadequação de seu despejo.

$\mathrm{O}$ ábaco chinês ${ }^{22}$ é considerado um importante marco histórico e revolucionário para a produção destes bens, já que foi o primeiro instrumento da humanidade destinado aos cálculos. Muitos anos depois, o filósofo, físico e matemático francês Blaise Pascal (1623-1662) desenvolveu, em 1642, a primeira calculadora me-

\footnotetext{
${ }^{22}$ POMBO, Olga. The Abacus. "O registro mais antigo que se conhece é um esboço presente num livro da dinastia Yuan (século XIV). O seu nome em Mandarim é "Suan Pan" que significa "prato de cálculo". O ábaco chinês tem 2 contas em cada vareta de cima e 5 nas varetas de baixo razão pela qual este tipo de ábaco é referido como ábaco 2/5. O ábaco 2/5 sobreviveu sem qualquer alteração até 1850 , altura em que aparece o ábaco do tipo $1 / 5$, mais fácil e rápido. Os modelos $1 / 5$ são raros hoje em dia, e os $2 / 5$ são raros fora da China exceto nas suas comunidades espalhadas pelo mundo." 2010.p.01.Mini Web Educação. Disponível em: < http://www. miniweb.com.br/ciencias/artigos/abaco_historia.html > . Acesso em: 20 de março de 2016.
} 
cânica do mundo, a Pascaline ${ }^{23}$, que realizava operações matemáticas de soma e subtração. O matemático Gottfried Wilhelm Von Leibniz ${ }^{24}$ buscou aprimorar o sistema da calculadora de Pascal, e, em 1672, construiu a calculadora mecânica nominada como stepped reckoner, que fazia as quatro operações básicas e a raiz quadrada dos números. Apesar dos grandes avanços, este aparelho ainda demandava aperfeiçoamento, já que trazia alguns resultados equivocados. O padre alemão Philipp Matthäus Hahn ${ }^{25}$ sofisticou este sistema em 1774, projetando uma calculadora que realizava perfeitamente as quatro operações matemáticas (adição, subtração, multiplicação e divisão). Um elemento limitador, entretanto, era a impossibilidade de inserção de novas funções, pois somente eram viáveis as operações que já estavam previamente programadas.

Esta questão foi superada com o invento do mecânico e costureiro francês, Joseph Marie Jacquard, ${ }^{26}$ em 1801 - o Tear Programável. Observando o tempo que demorava a concluir as atividades de desenhos em tecidos, e a complexidade para a reprodução sequencial dos mesmos, Joseph construiu uma máquina programável, que aceitava cartões perfuráveis para poder recortar os tecidos de maneira automática. Esta leitura da programação influenciou profundamente tanto a tecelagem quanto, posteriormente, o ramo de produção de computadores. A evolução das máquinas é uma das consequências da necessidade de aceleração do ritmo de produção, imprimido pela sociedade industrial.

Com a Segunda Guerra Mundial (1939-1945) e a demanda pela precisão de táticas de defesa e ataques, eram fundamentais mecanismos e recursos tecnológicos capazes de apresentarem com exatidão cálculos para que as estratégias táticas e militares fossem tomadas. Daí a relevância do $\mathrm{ENIAC}^{27}$, um maquinário gigantesco que funcionava por meio do acionamento de válvulas. Apesar deste importante passo

${ }^{23}$ FARIAS, Gilberto. Introdução à Computação. 2014.p.25. Disponível em: < http://producao.virtual.ufpb.br/ books/camyle/introducao-a-computacao-livro/livro/livro.chunked/index.html > . Acesso em: 10 mar. 2016.

${ }^{24}$ FREIBERGER, Paul A. SWAINE, Michael R. Calculating Machine. Step reckoner. 10 jul. 2008. Disponível em: $<$ https:/global.britannica.com/technology/Step-Reckoner>. Acesso em: 20 out. 2016.

${ }^{25}$ History Computer. Philipp Matthäus Hahn. 2010. Disponível em: < http://history-computer.com/MechanicalCalculators/18thCentury/Hahn.html > . Acesso em: 15 nov. 2016.

${ }^{26}$ FARIAS, Gilberto. Introdução à Computação. 2014.p.25. Disponível em: < http://producao.virtual.ufpb.br/ books/camyle/introducao-a-computacao-livro/ivro/ivro.chunked/index.html > . Acesso em: 10 mar. 2016.

${ }^{27}$ Nas lições de Musardo: "Em 1946, era anunciado o nome do primeiro computador digital eletrônico de grande escala: o ENIAC (Electrical Numerical Integrator and Calculator). Criado pelos cientistas norte-americanos John Presper Eckert e John W. Mauchly, da Electronic Control Company, o ENIAC pesava 30 toneladas e ocupava uma área de $270 \mathrm{~m}^{2}$ de área construída. O primeiro computador digital eletrônico, o ENIAC, não tinha sistema operacional e seu funcionamento era parecido com uma calculadora simples de hoje. O ENIAC, assim como uma calculadora, tinha de ser operado manualmente." MUSARDO, Fernando. Primeiro Computador Digital Eletrônico - ENIAC. 2014.p.01. Disponível em: < http://musardos.com/1946/08/31/primeiro-computador-digital-eletronico-eniac/> . Acesso em: 20 mar. 2016. 
tecnológico, havia a necessidade de compactar o tamanho destas máquinas. A dedicação de William Shockley, juntamente com outros cientistas da Bell Telephone Company, foi primordial para esta redução, pois as suas pesquisas permitiram que as válvulas fossem substituídas por transistores, componentes bem menores.

O processo de compactação foi essencial para o desenvolvimento dos computadores pessoais (personal computers, os PCs). O Universal Automatic Computer (UNIVAC) $)^{28}$, de origem americana, foi o primeiro computador comercial de grande escala produzido. Coube ao Massachusetts Institute of Technology (MIT) o desenvolvimento do Whirlwind ${ }^{29}$, o primeiro computador a processar informações em tempo real, com entrada de dados a partir de fitas perfuradas e saída via monitor de vídeo. Com base neste sistema modernizado, foi possível o desenvolvimento dos microprocessadores. A partir da década de 1990, as principais características dos computadores foram os sistemas inteligentes e as redes neurais artificiais (RNAs), conceituadas por Elson Felix Mendes Filho ${ }^{30}$ como

As técnicas computacionais que apresentam um modelo matemático inspirado na estrutura neural de organismos inteligentes e que adquirem conhecimento por meio da experiência. Uma grande rede natural artificial pode possuir centenas ou mesmo milhares de unidades de processamento, enquanto que o cérebro humano pode ter bilhões de neurônios.

A tecnologia permanece sendo constantemente aprimorada, o que permite maior rapidez e segurança nos processamentos de dados. Tendo em vista que a sociedade contemporânea se encontra em franca expansão tecnológica e que estes aparelhos são utilizados nas mais diversas atividades humanas (como no trabalho e no estudo - inclusive em sua modalidade a distância, na comunicação ${ }^{31}$, no lazer, nas pesquisas, em investimentos na Bolsa de Valores etc), é fundamental a discussão acerca da conscientização das pessoas sobre o correto descarte de lixo eletrônico para a proteção humana e ambiental. É necessário observar que a situação se agrava

${ }^{28}$ Este invento ocorreu em 1951. Sua estrutura era composta pelo ajuste de aproximadamente 6.000 chaves ligadas por cabos a um painel. In. Computer History. Univac. 2015. Disponível em: < http://www.computerhistory.org/timeline/search/?q=univac > . Acesso em: 21 set. 2016.

${ }^{29}$ MIT Institute Archives \& Special Collections. Project Whirlwind. Jul. 2009. Disponível em: < https:/libraries. mit.edu/archives/exhibits/project-whirlwind/> . Acesso em: 10 nov. 2016.

${ }^{30}$ MENDES FILHO, Elson Felix. Redes neurais artificiais. Instituto de Ciências Matemáticas e de Computação. Universidade de São Paulo. 2000. Disponível em: < http://www.icmc.sc.usp.br/> . Acesso em: 01 set. 2016.

${ }^{31}$ Existem diversos recursos de comunicação via rede de aplicativos, tais quais: whatsapp messenger, viber: free calls e messenges, kik messenger, skype, facetime, etc. As versões atualizadas destes programas ensejam a troca dos celulares por aparelhos cada vez mais modernos, para que exista compatibilidade entre os celulares e os sistemas destes aplicativos. 
com a cultura do consumo ${ }^{32}$, responsável pela existência de ciclos de substituição de equipamentos cada vez mais acelerados e uma relação direta com o aumento da produção do lixo eletrônico, o que acarreta graves impactos socioambientais, mundialmente reconhecidos como um risco emergente para a saúde humana e para o meio ambiente pelos grandes volumes de substâncias tóxicas gerados.

No processo de fabricação de muitos destes equipamentos são utilizados diversos metais considerados pesados (como o ouro ${ }^{33}$, a prata e o cobre) que, se forem descartados incorretamente, poluem solos e lençóis freáticos ${ }^{34}$. A presença destes metais no ambiente influencia diretamente no desenvolvimento das atividades agrícolas e agropecuárias. Nakano e Avila-Campos discorrem sobre alguns dos efeitos decorrentes dos metais pesados ${ }^{35}$ :

Os efeitos tóxicos dos metais sempre foram considerados como eventos de curto prazo, agudos e evidentes, como anuria e diarreia sanguinolenta, decorrentes da ingestão de mercúrio. Atualmente, ocorrências a médio e longo prazo são observadas, e as relações causa-efeito são pouco evidentes e quase sempre subclínicas. Geralmente esses efeitos são difíceis de serem distinguidos e perdem em especificidade, pois podem ser provocados por outras substâncias tóxicas ou por interações entre esses agentes químicos. A manifestação dos efeitos tóxicos está associada à dose e pode distribuir-se por todo o organismo, afetando vários órgãos, alterando os processos bioquímicos, organelas e membranas celulares.

\footnotetext{
32 Nas lições de Gisela Taschner: "A cultura do consumo é tomada por nós como a presença generalizada em uma comunidade ou em toda a sociedade, de uma valoração positiva do consumo e de uma predisposição para consumir, particularmente certos itens - os quais variam no tempo e no espaço social". TASCHNER, Gisela. Cultura do consumo, cidadania e movimentos sociais. Revista Ciências Sociais Unissinos. Jan/abril 2010. Disponível em: $<$ http://revistas.unisinos.br/index.php/ciencias_sociais/article/viewFile/170/40> . Acesso em: 21 nov. 2016.

33 O cientista e médico brasileiro Sérgio Ulhoa Dan desenvolve pesquisas acerca dos problemas de saúde humana decorrentes da contaminação pelo ouro: "Há muitos anos ele estuda o caso e explica que o responsável pelas doenças é um material conhecido como arsênio, presente na poeira oriunda da mineração de ouro. Em artigo, Sérgio explica que o arsênio é parte das rochas onde se encontra o ouro e o material é liberado com a exploração. O arsênio é um dos agentes cancerígenos mais potentes e persistentes. É absorvido via oral ou respiratória e literalmente gruda nos ossos e mata de câncer e de várias outras doenças". Brasil de fato. Especialistas denunciam grave contaminação ambiental na maior mina de ouro do País. 06 de fevereiro de 2015. Disponível em: < http://www.brasildefato.com.br/node/31283>. Acesso em: 12 mar. 2016.

${ }^{34}$ Os lençóis freáticos são reservatórios de águas subterrâneas, alimentados pela água da chuva. O solo contaminado os atinge diretamente. Abaixo dos lençóis freáticos encontra-se a água da zona de saturação (região encharcada de água). Por estar localizada em área mais aprofundada, esta demora mais tempo do que os lençóis freáticos para ser contaminada. Percebemos, entretanto, que, apesar desta profundidade, caso a contaminação permaneça, e não sejam tomadas providências, a infiltração de resíduos poluentes continua se alastrando e atingindo áreas cada vez mais distantes do solo.

${ }^{35}$ NAKANO, Viviane. AVILA-CAMPOS, Mário Julio. Metais Pesados: Um perigo iminente. 2014. Departamento de Microbiologia. Universidade de São Paulo. Disponível em: < http://www.icb.usp.br/> . Acesso em: 10 mar. 2016. Os autores também observam que "As principais fontes de exposição aos metais tóxicos são os alimentos, observando-se um elevado índice de absorção gastrointestinal. Em adição aos critérios de prevenção usados em saúde ocupacional e de monitorização ambiental, a biomonitorização tem sido utilizada como indicador biológico de exposição, e toda substância ou seu produto de biotransformaçã̃o, ou qualquer alteração bioquímica observada nos fluídos biológicos, tecidos ou ar exalado, mostra a intensidade da exposição e/ou a intensidade dos seus efeitos". Idem.
} 
A amplitude dos danos é um fator muito preocupante: além da contaminação da biota e dos residentes no local, quem ingere estes alimentos, bem como quem trabalha diretamente com reciclagem contaminada pelo descarte incorreto sofre com estes severos impactos, pois os materiais são bioacumulativos ${ }^{36}$. As campanhas de conscientização são importantes instrumentos para que sejam pensadas alternativas para a reversão deste quadro. Em 2003, a publicação do slogan "Educação ambiental para um Brasil de todos ${ }^{37 "}$ sintetizou a relevância deste recurso de extrema valia para a contenção destes altos níveis de poluição, pois

A educação ambiental assume assim a sua parte no enfrentamento dessa crise radicalizando seu compromisso com mudanças de valores, comportamentos, sentimentos e atitudes, que deve se realizar junto à totalidade dos habitantes de cada base territorial, de forma permanente, continuada e para todos. Uma educação que se propõe a fomentar processos continuados que possibilitem o respeito à diversidade biológica, cultural, étnica, juntamente com o fortalecimento da resistência da sociedade a um modelo devastador das relações de seres humanos entre si e destes com o meio ambiente.

Insta salientar, entretanto, que as pessoas devem efetivamente ter acesso a estes recursos, daí a importância das medidas de divulgação acerca da nocividade deste material, além dos pontos de descarte e coleta do lixo eletrônico. A própria tecnologia vem sendo utilizada para esta finalidade. Os estudantes universitários Cássia Liliane Cavalcante e Anderson Tavares, do Curso de Ciências Ambientais da Universidade Federal do Ceará (UFC) desenvolveram em 2016 o aplicativo "DescarteINFO", com o mapeamento atualizado dos locais de coleta de diversos tipos de

\footnotetext{
${ }^{36}$ Desde 26 de agosto de 2010 o Brasil está comprometido com a ONU para reforçar o banimento das substâncias poluentes nominadas de poluentes orgânicos persistentes (POP). Platonow explica que: "A ONU já havia divulgado uma lista com 12 POPs, que agora será acrescida de mais nove, totalizando 21 substâncias com recomendação de banimento em todo o mundo. São elementos químicos que permanecem durante muito tempo na natureza, sendo absorvidos pelos animais em toda a cadeia alimentar, chegando até os seres humanos, onde se depositam principalmente nas camadas gordurosas, podendo gerar doenças nervosas, imunológicas, reprodutivas e câncer". PLATONOW, Vladimir. Brasil apoia medidas da ONU para banir substâncias químicas poluentes. Agência Brasil. Empresa Brasil de Comunicação. 26 ago 2010. Disponível em: <http://memoria. ebc.com.br/agenciabrasil/noticia/2010-08-26/brasil-apoia-medidas-da-onu-para-banir-substancias-quimicas-poluentes >. Acesso em: 21 nov. 2016.

${ }^{37}$ UNESCO. Vamos cuidar do Brasil: conceitos e práticas em educação ambiental na escola. Coordenação: Soraia Silva de Mello, Rachel Trajber. - Brasília: Ministério da Educação, Coordenação Geral de Educação Ambiental: Ministério do Meio Ambiente, Departamento de Educação Ambiental, 2007. p.15. Disponível em: < http://portal.mec.gov.br/secad/arquivos/pdf/educacaoambiental/educacaoambiental_naescola.pdf $>$. Acesso em: 10 nov. 2016.
} 
materiais $^{38}$ :

O aplicativo dispõe de informações sobre os materiais recebidos em cada local, endereço, telefone e funcionamento dos pontos de descarte, a rota até cada ponto e a categorização de resíduos e utensílios. Com a ferramenta, os usuários podem saber onde podem descartar corretamente os seguintes materiais: celulares, cartuchos, eletrodomésticos, eletrônicos, embalagens de vidro, embalagens do tipo longa vida (como caixas de leite), entulho, resto de poda, garrafas PET, lâmpadas, livros, medicamentos, metais, móveis velhos, óleo e gordura residenciais, papel, papelão, pilhas e baterias, plásticos, roupas, banners de lona, tampinhas de garrafas PET e cartões de plástico. Atualmente, o DescarteINFO está disponível para download gratuito na GooglePlay (para celulares ou tablets com sistema operacional Android) e App Store (para iphones e ipads, que utilizam o sistema iOS).

Ações desta natureza são fundamentais para que o fortalecimento da cultura acerca da necessidade de preservação ambiental e descarte correto de lixo eletrônico estejam presentes no cotidiano e ao alcance das pessoas.

\section{DESCARTE INCORRETO DO LIXO ELETRÔNICO}

A Organização das Nações Unidas (ONU) publicou, em 2009, o relatório "Recycling -from e-waste to resources" traduzido para o português como "Reciclando - Do lixo eletrônico a recursos", apontando que a maioria dos eletrodomésticos e aparelhos comuns em casas e empresas contém dezenas de componentes nocivos à saúde humana e ao meio ambiente (Programa das Nações Unidas para o meio ambiente - PNUMA, 2010). Em continuidade à análise do tema, a ONU calcula que a partir do ano 2017 o mundo terá aproximadamente 50 milhões de toneladas de lixo eletrônico, especialmente em decorrência da produção de computadores e smartphones $^{39}$. Os resíduos computacionais, resíduos eletrônicos ou lixo eletrônico também são gerados pelo descarte inadequado de diversos outros produtos, tais quais:

\footnotetext{
${ }^{38}$ UFC. Universidade Federal do Ceará. Estudantes da UFC desenvolvem aplicativo que lista pontos adequados para descarte de materiais. 01 jun.2016. Disponível em: < http://www.ufc.br/noticias/noticias-de-2016/8345-estudantes-da-ufc-desenvolvem-aplicativo-que-lista-pontos-adequados-para-descarte-de-materiais $>$. Acesso em: 20 jan. 2017.

39 Organização das Nações Unidas. Brasil produziu 1,4 milhão de toneladas de resíduos eletrônicos em 2014, afirma novo relatório da ONU. 20 de maio de 2015. Disponível em: < https://nacoesunidas.org/brasil-produziu-14-milhao-de-toneladas-de-residuos-eletronicos-em-2014-afirma-novo-relatorio-da-onu/ $>$. Acesso em: 10 mar. 2016.
} 
aparelhos de televisão, notebooks, tablets, rádios, geladeiras, refrigeradores, impressoras, scanners, cabos, roteadores, bome theaters, agendas eletrônicas, calculadoras, brinquedos eletrônicos, placas de circuito lógico etc. Trata-se de reflexo direto da sociedade atual, que se encontra cada vez mais informatizada e interconectada.

Com os avanços tecnológicos e a sofisticação recorrente destes aparelhos ${ }^{40}$, além da facilidade de parcelamento de compra (para estímulo do consumo), muitos consumidores os trocam rapidamente e, consequentemente, se estes bens eletroeletrônicos não são corretamente descartados, há grande acúmulo de sucata altamente poluente. O descarte destes dispositivos no local destinado ao lixo comum libera radiação que contamina o ambiente e prejudica a saúde humana.

A Comunidade Europeia ${ }^{41}$, pioneira na análise da gravidade da situação e preocupada com a destinação final e com descarte dos produtos eletroeletrônicos, aprovou, em 2003, duas diretrizes políticas de impactos globais voltadas à gestão dos resíduos de produtos eletroeletrônicos. São elas: Waste Eletrical and Electronic Equipment (WEEE) e Restriction of Certain Hazardous Substances, ou Restrição de Certas Substâncias Perigosas (RoHs) ${ }^{42}$. Estes documentos têm cunho inovador justamente por se pautarem nos seguintes princípios: poluidor pagador, precaução e na responsabilidade estendida do produtor, abrangendo toda a cadeia produtiva, buscando medidas para a coleta deste material a ser reciclado e incluindo considerações acerca do processo de reciclagem, direcionando todas estas diretrizes para a proteção ambiental, diminuindo a contaminação advinda da produção tecnológica nos recursos naturais. A Restriction of Certain Hazardous Substances (RoHs, Diretiva

\footnotetext{
${ }^{40}$ Nos dizeres de Denis Alcides Rezende: "a informática ou tecnologia da informação pode ser conceituada como recursos tecnológicos e computacionais para guarda, geração e uso da informação e do conhecimento. Está fundamentada nos seguintes componentes: hardware e seus dispositivos e periféricos; software e seus recursos; sistemas de telecomunicações; gestão de dados e informações. Todos estes componentes interagem e necessitam do componente fundamental, que é o recurso humano peopleware ou humanware. Embora conceitualmente este componente não faça parte da tecnologia da informação, sem ele esta tecnologia não teria funcionalidade e utilidade". REZENDE, Denise Alcides. Planejamento de sistemas de informação e informática: guia prático para planejar a tecnologia da informação integrada ao planejamento estratégico das organizações. São Paulo: Atlas, 2003, p. 68.

${ }^{41}$ European Commision. Enviroment. Waste of electrical and electronic equipment (WEEE). 09 jun. 2016. Disponível em: <http://ec.europa.eu/environment/waste/weee/index_en.htm>. Acesso em: 15 out. 2016.

${ }^{42}$ Essas exigências incorporam a responsabilidade do produtor (produtor, distribuidor ou importador). As informações estão disponíveis em: Waste Electrical and Electronic Equipment (WEEE). 2015. Disponível em: <ec. europa.eu/environment/waste/weee/index_en.htm >. Acesso em: 11 mar. 2016.
} 
2002/95/EC $\left.{ }^{43}\right)$, também conhecida como "lei do sem chumbo" ou "lead-free" ${ }^{44}$, é de extrema relevância por proibir a utilização de diversas substâncias perigosas e tóxicas na fabricação de produtos, tais quais: mercúrio, cromo e chumbo.

\subsection{CONDUTAS DOLOSAS, CULPOSAS E O CRIME AMBIENTAL}

Os aparelhos são classificados pela Associação Brasileira da Indústria Elétrica e Eletrônica ${ }^{45}$ (ABINEE) em quatro categorias amplas: Linha Verde, Linha Marrom, Linha Branca e Linha Azul. Cada uma delas possui características relativas à vida útil, ao porte de equipamentos integrantes, à diversidade de componentes e às principais composições. A Linha Branca ${ }^{46}$ (cujos equipamentos são compostos principalmente por metais) engloba refrigeradores, congeladores, fogões, lavadoras de roupa, lavadoras de louça, secadoras e condicionadores de ar. A Linha Marrom ${ }^{47}$, por sua vez, abrange monitores e televisores de tubo, plasma, LCD e LED, aparelhos de DVD e VHS, equipamentos de áudio e filmadoras (estes aparelhos são compostos principalmente por plástico e vidro). A Linha Azull ${ }^{48}$ (fabricada especialmente em plástico) é composta por batedeiras, liquidificadores, ferros elétricos, secadores de cabelo etc. Finalmente a Linha Verde ${ }^{49}$, que se refere a computadores desktop e laptops, acessórios de informática, tablets e telefones celulares.

Os riscos de contaminação do meio ambiente dependem de vários fatores,

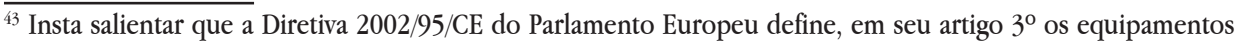
eletroeletrônicos (EEE) como: "Os equipamentos cujo funcionamento adequado depende de correntes elétrica ou campos eletromagnéticos, bem como os equipamentos para geração, transferência e medição dessas correntes e campos pertencentes às categorias definidas no Anexo I A da Diretiva 2002/96/CE e destinados à utilização com uma tensão nominal não superior a $1.000 \mathrm{~V}$ para corrente alternada e $1.500 \mathrm{~V}$ para corrente contínua" (PARLAMENTO EUROPEU, 2003).

${ }^{44}$ European Union Law. EUR-Law. 2010. Disponível em: < http://eur-lex.europa.eu/legal-content/PT/TXT/?uri=CELEX\%3A32011L0065> . Acesso em: 12 mar. 2016.

${ }^{45}$ ABINEE. Associação Brasileira da Indústria Elétrica e Eletrônica. 2012. Disponível em: < http://www.abinee. org.br/> . Acesso em: 20 ago. 2015.

${ }^{46}$ COSTA, Cláudia Soares. SOUZA, Adilson José de. SANTOS, Ângela Maria Medeiros. Bens de Consumo: Linha Branca. Eletrodomésticos. 2006. BNDES. Disponível em: < http://www.bndes.gov.br/SiteBNDES/export/sites/ default/bndes_pt/Galerias/Arquivos/conhecimento/bnset/set206.pdf>. Acesso em: 17 mar. 2016.

47 "Linha marrom: eletrodomésticos da linha dos eletroeletrônicos - aparelhos de televisão, aparelhos de som, DVD's players, CD players" In. MASCARENHAS, Henrique Ribeiro. O setor de eletrodomésticos de linha branca: um diagnóstico e a relação varejo-indústria. Mestrado em Finanças e Economia Empresarial. Faculdade Getúlio Vargas. São Paulo. 2005.p.10.

${ }^{48}$ Agência Brasileira de Desenvolvimento Industrial. O resíduo eletroeletrônico. Linha azul: batedeiras, liquidificadores, ferros elétricos, furadeiras, secadores de cabelo, espremedores de frutas, aspiradores de pó, cafeteiras. Logística Reversa de Equipamentos Eletroeletrônicos. Análise de viabilidade técnica e econômica. Brasília. 2012.p.17. Disponível em: < http://www.desenvolvimento.gov.br//arquivos/dwnl_1362058667.pdf>. Acesso em: 17 mar. 2016.

${ }^{49}$ Agência Brasileira de Desenvolvimento Industrial. O resíduo eletroeletrônico. Linha verde: computadores desktop e laptops, acessórios de informática, tablets e telefones celulares. Logística Reversa de Equipamentos Eletroeletrônicos. Análise de viabilidade técnica e econômica. Brasília. 2012.p.17. Disponível em: <http:// www.desenvolvimento.gov.br//arquivos/dwnl_1362058667.pdf>. Acesso em: 17 mar. 2016.
} 
como o comportamento do consumidor ao se desfazer do aparelho. Apesar dos parâmetros nacionais e internacionais destinados à referida proteção, na prática constata-se que muitas condutas humanas (dolosas ou culposas, ou seja, intencionais ou não intencionais) perpetuam a degradação ambiental. Os comportamentos que se amoldam aos tipos penalmente tipificados são punidos na esfera do direito penal. Neste ponto merece destaque especial a já citada lei $n^{0} .9605$, de $1998^{50}$, que dispõe sobre as sanções penais e administrativas das condutas lesivas ao meio ambiente além de trazer outras providências. As penas são estabelecidas de acordo com a gravidade das infrações. A lei inova também ao definir a responsabilidade das pessoas jurídicas, permitindo que grandes empresas sejam responsabilizadas criminalmente pelos danos que seus empreendimentos possam causar à natureza. Ademais, a lei $\mathrm{n}^{\mathrm{o}}$ 9.605/98 agrupa os crimes ambientais em cinco espécies: os crimes contra a fauna (previstos nos arts. 29 a 37); os crimes contra a flora (tipificados nos arts. 38 a 53); a poluição e outros crimes ambientais (expostos nos arts. 54 a 61); os crimes contra o ordenamento urbano e o patrimônio cultural (dispostos entre os arts. 62 a 65); e, por fim, os crimes contra a administração ambiental (arts. 66 a 69).

O descarte incorreto de lixo eletrônico (seja, por exemplo, quando o infrator abandona estes resíduos em local indevido ou quando os descarta junto com o lixo comum) causa grandes prejuízos e tem seus efeitos ampliados ao entrar em contato com solos e lençóis freáticos e contaminá-los. Amato Neto ${ }^{51}$ esclarece que "a crise ambiental se agrava com a crescente emissão de gases, metais, contaminação da água, a erosão dos solos, a desertificação de vastas regiões do planeta, a perda da diversidade da fauna e da flora. Além dos metais pesados, estes aparelhos têm diversos componentes como os metais, o vidro e o plástico, o que acarreta a estes

\footnotetext{
$\overline{{ }^{50} \text { BRASIL. Lei } \mathrm{n}^{\circ} .9 .605}$, de 12 de fevereiro de 1998: dispõe sobre as sanções penais e administrativas derivadas de condutas e atividades lesivas ao meio ambiente, e dá outras providểncias. Esta legislação tipifica condutas dolosas e culposas: "Art. 54. Causar poluição de qualquer natureza em níveis tais que resultem ou possam resultar em danos à saúde humana, ou que provoquem a mortandade de animais ou a destruição significativa da flora: Pena - reclusão, de um a quatro anos, e multa. $\S 1^{\circ}$ Se o crime é culposo: Pena - detenção, de seis meses a um ano, e multa. Art. 56. Produzir, processar, embalar, importar, exportar, comercializar, fornecer, transportar, armazenar, guardar, ter em depósito ou usar produto ou substância tóxica, perigosa ou nociva à saúde humana ou ao meio ambiente, em desacordo com as exigências estabelecidas em leis ou nos seus regulamentos: Pena - reclusão, de um a quatro anos, e multa. §10 Nas mesmas penas incorre quem: (Redação dada pela Lei $n^{0} 12.305$, de 2010) I - abandona os produtos ou substâncias referidos no caput ou os utiliza em desacordo com as normas ambientais ou de segurança; (Incluído pela Lei $\mathrm{n}^{\circ} 12.305$, de 2010) II - manipula, acondiciona, armazena, coleta, transporta, reutiliza, recicla ou dá destinação final a resíduos perigosos de forma diversa da estabelecida em lei ou regulamento. (Incluído pela Lei $n^{\circ}{ }^{52.305}$, de 2010) $§ 3^{\circ}$ Se o crime é culposo: Pena - detenção, de seis meses a um ano, e multa. (grifo nosso)".

${ }^{51}$ AMATO NETO, João. Os desafios da produção e do consumo sob novos padrões sociais e ambientais. In: AMATO NETO, João. Sustentabilidade e Produção: teoria e prática para uma gestão sustentável. São Paulo: Atlas, 2011.p.10-12.
} 
materiais a difícil decomposição" 52 .

A tipificação da conduta não é suficiente para que este comportamento seja evitado. São também necessárias medidas destinadas à implementação de políticas públicas que garantam meios de combate a este tipo de contaminação ambiental, além de recursos que permitam que o descarte seja realizado de maneira adequada. A respeito da temática, destaca-se a ILei $\mathrm{n}^{\mathrm{o}}$. 12.305/2010 que define em seu art. $3^{\circ}$, XII, a logística reversa como sendo $0^{53}$

Instrumento de desenvolvimento econômico e social caracterizado por um conjunto de ações, procedimentos e meios destinados a viabilizar a coleta e a restituição dos resíduos sólidos ao setor empresarial, para reaproveitamento, em seu ciclo ou em outros ciclos produtivos, ou outra destinação final ambientalmente adequada.

Nos dizeres de Paulo Roberto Leite ${ }^{54}$

A logística reversa define-se como a área da Logística Empresarial que planeja, opera e controla o fluxo, e as informações logísticas correspondentes, do retorno dos bens de pós-venda e de pós-consumo ao ciclo de negócios ou ao ciclo produtivo, através dos Canais de distribuição reversos, agregando-lhes valor de diversas naturezas: econômico, ecológico, legal, logístico, de imagem corporativa, entre outros.

O sucesso para a implementação destas medidas enseja um empenho coletivo, abrangendo as etapas de produção dos materiais, além da postura adotada tanto no período pré-vendas quanto no pós-venda destes bens. Portanto estes são importantes passos que permitem o envolvimento de produtores, fornecedores, empresários, vendedores e consumidores para que o meio ambiente seja protegido.

\section{POLÍTICAS PÚBLICAS EDUCACIONAIS AMBIENTAIS, SUSTENTABILIDADE E PRESERVAÇÃO DA BIOTA}

\footnotetext{
${ }^{52}$ Dados disponibilizados pela Universidade Federal de São Paulo (Unifesp) para apresentação do período previsto para a decomposição de diversos resíduos descartados: "Papel: de 3 meses a vários anos; Lata de aço: 10 anos; Embalagem longa vida: mais de 100 anos ; Plásticos: mais de 100 anos; Latas de alumínio: mais de 1.000 anos; Vidro: mais de 10.000 anos". Universidade Federal de São Paulo. Projeto Ecounifesp. 2010. Disponível em: < http://dgi.unifesp.br/ecounifesp>. Acesso em: 31 mar. 2016.

${ }^{53}$ BRASIL. Lei ${ }^{0}$. 12.305, de 02 de agosto de 2010: Institui a Política Nacional de Resíduos Sólidos; altera a Lei no 9.605 , de 12 de fevereiro de 1998 e dá outras providências.

${ }^{54}$ LEITE, Paulo Roberto. Logística reversa. São Paulo: Pearson Prentice Hall, 2003, p. 22.
} 
Previamente foi esclarecido que a Constituição Federal Brasileira de 1988 compartilha a responsabilidade da preservação ambiental entre os entes públicos e privados, entre pessoas físicas e jurídicas. A organização desta rede colaborativa enseja o diálogo entre os atores sociais, para que as ações sejam planejadas, definidas e aplicadas. Trata-se das políticas públicas, assim definidas por Maria Paula Dallari Bucci $^{55}$ :

Política pública é o programa de ação governamental que resulta de um processo ou conjunto de processos juridicamente regulados processo eleitoral, processo de planejamento, processo de governo, processo orçamentário, processo legislativo, processo administrativo, processo judicial - visando coordenar os meios à disposição do Estado e as atividades privadas, para a realização de objetivos socialmente relevantes e politicamente determinados. Como tipo ideal, política pública deve visar a realização de objetivos definidos, expressando a seleção de prioridades, a reserva de meios necessários à sua consecução e o intervalo de tempo em que se espera o atingimento dos resultados.

Cinco são as etapas que as compõem ${ }^{56}$ : identificação do problema; formulação das políticas públicas; processo de tomada de decisões; implementação; e, por fim, a avaliação. Em uma abordagem sintética, é possível destacar os principais pontos de cada fase. Tendo em vista que a elaboração de uma política pública demanda a definição acerca das necessidades prioritárias, a primeira etapa deve cuidar da análise dos dados para a identificação do problema, bem como dos recursos disponíveis para a sua execução. Superada esta questão e estabelecido o tema, na segunda etapa devem ser definidos os objetivos da política pública, os programas a serem desenvolvidos, além de suas frentes de ação. A terceira fase, por sua vez, é destinada à definição cronológica destas ações. Em seguida, a quarta etapa tem como característica a aplicabilidade prática de todo o planejamento e todas as ações da política pública. Por fim, a quinta fase é dedicada às análises e avaliações dos resultados positivos e pontos que precisam ser aprimorados da referida política.

As políticas públicas estão em constantes transformações, pois a sociedade apresenta reiteradamente novas demandas. Daniel Fonseca de Andrade ${ }^{57}$ discorre sobre o lugar do diálogo nas políticas públicas de educação ambiental e entende que

\footnotetext{
55 BUCCI, Maria Paula Dallari. O conceito de política pública em direito. In Políticas Públicas: reflexões sobre o conceito jurídico. Maria Paula Dallari Bucci (organizadora). São Paulo: Saraiva, 2006, p.39.

${ }^{56}$ Agenda 21. As cinco fases das políticas públicas. 18 de outubro de 2013. Disponível em: < http://www.agenda21 comperj.com.br/noticias/cinco-fases-das-politicas-publicas > . Acesso em: 17 mar. 2016.

${ }^{57}$ ANDRADE, Daniel Fonseca de. O lugar do diálogo nas políticas públicas de educação ambiental. Tese (Doutorado) - Universidade de São Paulo. Programa de Pós Graduação em Ciência Ambiental. São Paulo. 2013, p.22.
} 
É necessária a criação de condições de fomento, que levem em consideração todas as dimensões do diálogo e do exercício da prática dialógica, inclusive com a incorporação de métodos e técnicas que valorizem a multivocalidade. Educadores e educadoras, gestores e gestoras envolvidos em processos de construção de políticas públicas por meio do diálogo devem, assim, aprender sobre pressupostos, os indicadores, os obstáculos, os métodos e os instrumentos de avaliação do diálogo, para constantemente aperfeiçoar suas próprias experiências individuais e coletivas.

Diversas ações desenvolvidas em ambiente universitário aproximam a comunidade das medidas destinadas à proteção ambiental. A Universidade de São Paulo mantém desde 2008 o Centro de Descarte e Reúso de Resíduos de Informática $(\mathrm{CEDIR})^{58}$. Este projeto tem por objetivo reciclar os detritos eletroeletrônicos como mouses, teclados, CPU, monitores, impressoras, scanners, CDs, DVDs, WebCams, telefones, celulares de forma sustentável. Os destinos das peças são diversos. Alguns bens são destinados à doação e os que não podem ser desta forma utilizados são desmontados e encaminhados aos recicladores cadastrados, que tratam adequadamente do material. À Universidade Estadual de São Paulo ${ }^{59}$ cabe cuidar do projeto Polo de Reciclagem de Eletroeletrônicos (PREEL), concebido no campus de Guaratinguetá da Unesp em setembro de 2010 e implantado visando destinar corretamente o lixo tecnológico atendendo os padróes de sustentabilidade e cidadania. Ademais, a campanha de coleta de lixo eletrônico, ocorrida em 2012 no Centro Universitário Cesumar, ${ }^{60}$ teve excelentes resultados.

Somente em dois dias - terça e quarta-feira desta semana -, mais de 2,5 toneladas de sucata foram doadas pela população, empresas da cidade e o público acadêmico. Segundo o professor Paulo Pardo, responsável pela organização, a coleta superou as expectativas. "Para nós, o importante foi ter sensibilizado as pessoas para que trouxessem até a instituição o material que estava obsoleto em suas casas, conscientizando-se de que são altamente poluentes e não podem ser descartados no meio ambiente", disse ele. Milhares de pilhas, baterias, celulares, além de aparelhos de TV, rádio, DVD, computadores e impressoras, entre outros, foram coletados.

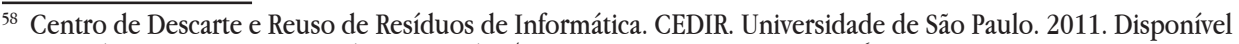
em: <http://www.puspc.usp.br/?page id=4705> . Acesso em: 23 out. 2016.

59 Polo de Reciclagem de Eletroeletrônicos. PREEL. Universidade Estadual de São Paulo. 2010. Disponível em: $<$ http://www.feg.unesp.br/ preel/first.html > . Acesso em: 02 set. 2016.

${ }^{60}$ UniCesumar. Assessoria de Imprensa. Cesumar coleta mais de 2,5 toneladas de lixo eletrônico. 08 de junho de 2012. Disponível em: <http://www.unicesumar.edu.br/imprensa/noticia.php?idNoticia=1991>. Acesso em: 30 mar. 2016.
} 
Os projetos são fundamentais para o fortalecimento e aprimoramento do diálogo, além da conscientização acerca da importância do restauro e reutilização dos equipamentos eletroeletrônicos que estiverem em condições; e do descarte correto nos casos em que a restauração é impossível ${ }^{61}$. Estas medidas representam grandes passos na busca pela preservação da biota, e é necessário o fortalecimento da cultura da educação ambiental bem como a ampliação de políticas públicas voltadas a este foco. Espera-se que, com iniciativas desta natureza, seja adotado novo posicionamento acerca do lixo eletrônico, protegendo o meio ambiente, a vida humana e estimulando um novo veio de mercado de trabalho.

\section{CONSIDERAÇÕES FINAIS}

A Constituição Federal Brasileira de 1988, em harmonia com diversos diplomas internacionais, consagra a responsabilidade da coletividade na busca pela proteção do meio ambiente, prevendo, para tanto, o envolvimento do Poder Público e da sociedade na luta pela preservação ambiental bem como pela tutela dos direitos difusos e coletivos das presentes e futuras gerações.

Um dos grandes problemas da atualidade é o descarte incorreto do lixo eletrônico. A tecnologia e a globalização, que estão presentes no cotidiano e são de imensurável importância para as pessoas, apresentam também diversos pontos desfavoráveis, como a degradação e contaminação ambiental. O descarte inadequado de aparelhos eletroeletrônicos resulta em lixo eletrônico, que é altamente poluente e contaminante. Os metais pesados podem desencadear reações muito sérias para a saúde humana, como problemas pulmonares, sanguíneos e cancerígenos.

Frente a esta questão, é necessário que se procure soluções que minimizem estes danos. É urgente o debate acerca do fortalecimento de políticas públicas educacionais acessíveis e destinadas ao correto descarte do lixo eletrônico. Ao longo do presente texto foram apresentadas importantes medidas desenvolvidas em ambiente acadêmico para o fortalecimento da cultura do descarte correto do lixo eletrônico bem como para o envolvimento das pessoas para a efetividade da proteção ambien-

\footnotetext{
${ }^{61}$ As informações relacionadas à Universidade de São Paulo e à Universidade Estadual de São Paulo estão disponibilizadas na Reportagem Informa ABC acerca do lixo eletrônico. MENDES, Bruna. Lixo eletrônico. Informa ABC. São Bernardo do Campo. 10 de abril de 2013. Disponível em: < http://www.informaabc.com.br/regional/ id-27669/ixo_eletronico>.Acesso em: 31 mar. 2016.
} 
tal, tais quais: o uso de aplicativos e os pontos de coleta específicos para este fim.

Dessa forma, é possível gerar redes colaborativas e educacionais destinadas a minimizar os efeitos negativos decorrentes do descarte inadequado destes materiais, bem como o fortalecimento de ações de conservação da biodiversidade, da qualidade do ar, dos solos e dos recursos hídricos, além da implementação de medidas de gestão adequadas dos rejeitos sólidos eletrônicos.

\section{REFERÊNCIAS}

ABINEE. Associação Brasileira da Indústria Elétrica e Eletrônica. 2012. Disponível em: http://www.abinee.org.br/. Acesso em: 20 ago.2015.

Agência Brasileira de Desenvolvimento Industrial. Logística Reversa de Equipamentos Eletroeletrônicos. Análise de viabilidade técnica e econômica. Brasília. 2012. Disponível em: http://www.desenvolvimento.gov.br//arquivos/ dwnl_1362058667.pdf. Acesso em 17 de março de 2016.

Agenda 21. As cinco fases das políticas públicas. 18 de outubro de 2013. Disponível em: http://www.agenda21comperj.com.br/noticias/cinco-fases-das-politicas-publicas. Acesso em 17 de março de 2016.

ALEXY, Robert. Teoría de los derechos fundamentales. Trad. de Ernesto Garzón Valdés. Madrid: Centro de Estudios Políticos y Constitucionales. 3.a reimp. 2002.

AMATO NETO, João. Os desafios da produção e do consumo sob novos padrões sociais e ambientais. In: AMATO NETO, João. Sustentabilidade e Produção: teoria e prática para uma gestão sustentável. São Paulo: Editora Atlas, 2011.

AMORIM, João Alberto Alves. A Onu e o Meio Ambiente: Direitos Humanos, Mudanças Climáticas e Segurança No Século XXI. São Paulo: Atlas, 2015.

ANDRADE, Daniel Fonseca de. O lugar do diálogo nas políticas públicas de educação ambiental. Tese (Doutorado) - Universidade de São Paulo. Programa de Pós Graduação em Ciência Ambiental. São Paulo. 2013.

ANTUNES, Paulo de Bessa. Direito ambiental. 17. ed. São Paulo: Atlas, 2015. 
ARNAUD, André-Jean. $\mathrm{O}$ direito entre modernidade e globalização: lições de filosofia do direito e do Estado. Tradução de Patrice Charles Wuillaume. Rio de Janeiro: Renovar, 1999.

BAUDRILLARD, Jean. A sociedade de consumo. 3. ed. Lisboa: Edições 70, 2009.

BAUMAN, Zygmunt. Vida para consumo: a transformação das pessoas em mercadorias. Tradução de Carlos Alberto Medeiros. Rio de Janeiro: Jorge Zahar, 2008.

$\mathrm{BECH}$, Ulrich. La sociedad del riesgo mundial: em busca de la modernidad perdida. Tradução de Rosa S. Carbó. Barcelona: Paidós, 2008.

BECK, Ulrich. La sociedad Del riesgo: hacia una nueva modernidad. Barcelona, Buenos Aires. México: Paidós, 1998.

BENJAMIN, Antonio Herman. Constitucionalização do ambiente e ecologização da Constituição brasileira. São Paulo: Saraiva, 2008.

BOBBIO, Norberto. A Era dos Direitos. São Paulo: Elsevier Editora, 2004.

BOBBIO, Norberto. Teoria da norma jurídica. Tradução: Fernando Pavan Baptista e Ariani Bueno Sudatti. Bauru, SP: EDIPRO: 4 ed. Revista, 2008.

BRASIL. Constituição (1998). Constituição da República Federativa do Brasil. Brasília, DF: Senado Federal. Centro Gráfico, 1998. 292p.

BRASIL. Lei no . 6.938, de 31 de agosto de 1981: dispõe sobre a Política Nacional do Meio Ambiente. 1981.

BRASIL. Lei $\mathbf{n}^{\mathbf{0}}$. 9.605, de 12 de fevereiro de 1998: dispõe sobre as sanções penais e administrativas derivadas de condutas e atividades lesivas ao meio ambiente, e dá outras providências.

BRASIL. Lei $\mathbf{n}^{\mathbf{0}}$. 8.171, de 17 de janeiro de 1991: dispõe sobre a política agrícola.

BRASIL. Lei $\mathbf{n}^{\mathbf{0}}$. 12.305, de 02 de agosto de 2010: Institui a Política Nacional de Resíduos Sólidos; altera a Lei oํ 9.605, de 12 de fevereiro de 1998; e dá outras providências. 
Brasil de fato. Especialistas denunciam grave contaminação ambiental na maior mina de ouro do País. 06 de fevereiro de 2015. Disponível em: < http://www.brasildefato.com.br/node/31283 > . Acesso em: 12 mar. 2016.

BUCCI, Maria Paula Dallari. O conceito de política pública em direito. In Políticas Públicas: reflexões sobre o conceito jurídico. São Paulo: Saraiva, 2006.

Câmara dos Deputados. Comissão de Fiscalização Financeira e Controle - CFFC. Seminário - Políticas Públicas de Estimulo ao Consumo e seus Reflexos na Economia do Brasil. 2012. Disponível em: < http://www2.camara.leg.br/atividade-legislativa/comissoes/comissoes-permanentes/cffc/seminarios-e-outros-eventos/ seminario-politicas-publicas-de-estimulo-ao-consumo-e-seus-reflexos-na-economiado-brasil >. Acesso em: 10 fev. 2016.

CANOTILHO, José Joaquim Gomes. Direito Constitucional e Teoria da Constituição. 2. ed. Coimbra: Almedina, 1998.

CARVALHO, Délton Winter de; DAMACENA, Fernanda Dalla Libera. Direito dos Desastres. Porto Alegre: Livraria do Advogado, 2013.

Centro de Descarte e Reuso de Resíduos de Informática. CEDIR. Universidade de São Paulo. 2011. Disponível em: http://www.puspc.usp.br/?page_id $=4705$. Acesso em: 23 out. 2016.

Computer History. Univac. 2015. Disponível em: < http://www.computerhistory. org/timeline/search/?q=univac $>$. Acesso em: 21 set. 2016.

COSTA, Cláudia Soares. SOUZA, Adilson José de. SANTOS, Ângela Maria Medeiros. Bens de Consumo: Linha Branca. Eletrodomésticos. 2006. BNDES. Disponível em: $<$ http://www.bndes.gov.br/SiteBNDES/export/sites/default/bndes_pt/Galerias/Arquivos/conhecimento/bnset/set206.pdf> . Acesso em: 17 mar. 2016.

COSTA, José de Faria. Direito penal e globalização. Coimbra: Coimbra, 2010.

DELÉAGE, Jean Paul. História da Ecologia: Uma Ciência do Homem e da Natureza. Lisboa: Publicações Dom Quixote, 1993.

DERANI, Cristiane. Direito Ambiental Econômico. São Paulo: Saraiva: 2012. 
DIAS, Reinaldo. Gestão Ambiental: Responsabilidade Social e Sustentabilidade. 2. ed. São Paulo: Atlas, 2011.

DOUGLAS, Mary; ISHERWOOD, Baron. O Mundo dos Bens: para uma antropologia do consumo. Rio de Janeiro: Editora UFRJ, 2004.

European Commision. Enviroment. Waste of electrical and electronic equipment (WEEE). 09 jun. 2016. Disponível em: < http://ec.europa.eu/environment/waste/ weee/index_en.htm>.Acesso em: 15 out. 2016.

European Union Law. EUR-Law. 2010. Disponível em: < http://eur-lex.europa.eu/ legal-content/PT/TXT/?uri=CELEX\%3A32011L0065> . Acesso em: 12 mar. 2016.

FARIAS, Gilberto. Introdução à Computação. 2014. Disponível em: < http://producao.virtual.ufpb.br/books/camyle/introducao-a-computacao-livro/livro/livro.chunked/index.html > . Acesso em: 10 mar. 2016.

FIORILLO, Celso Antônio Pacheco. Curso de direito ambiental brasileiro. 14. ed. rev., ampl. e atual. em face da Rio+20 e do novo "Código" Florestal. São Paulo : Saraiva, 2013.

FONSECA FILHO, Cléuzio. História da computação [recurso eletrônico]: O Caminho do Pensamento e da Tecnologia. Porto Alegre: EDIPUCRS, 2007.

FREIBERGER, Paul A. SWAINE, Michael R. Calculating Machine. Step reckoner. 10 jul. 2008. Disponível em: <https:/global.britannica.com/technology/Step-Reckoner $>$. Acesso em: 20 out. 2016.

FREITAS, Juarez. Sustentabilidade: direito ao futuro. Belo Horizonte: Fórum, 2011.

FREITAS, Vladmir Passos de. A Constituição Federal e a Efetividade das Normas Ambientais. 3. ed. São Paulo: Revista dos Tribunais. 2005.

FREITAS, Vladimir Passos de (Coord.). Julgamentos Históricos do Direito Ambiental. Campinas: Milenium, 2010. 
GOIANIA. Secretaria de Estado de Gestão e Planejamento. Césio 137 a história do acidente radioativo em Goiânia. 2012. Disponível em: < http://www.cesio137goiania.go.gov.br/index.php?idEditoria=3823 > . Acesso em: 22 jan. 2017.

HAREL, David, The Spirit of Computing. 2. ed. Addison-Wesley Editor, 1992.

History Computer. Philipp Matthäus Hahn. 2010. Disponível em: < http:/historycomputer.com/MechanicalCalculators/18thCentury/Hahn.html $>$. Acesso em: 15 nov. 2016.

INES. The International Nuclear and Radiological Event Scale. International Conference: Goiânia, ten years later. Out. 1997. Disponível em: < http://www-ns.iaea. org/meetings/rw-summaries/goiania-1997.asp?s $=10 \& l=80>$. Acesso em: 22 jan. 2017.

Instituto de Matemática e Estatística da Universidade de São Paulo. IME. Como funciona um computador. 2012. Disponível em: < https://www.ime.usp.br/ elo/ IntroducaoComputacao/Como\%20funciona\%20um\%20computador.htm $>$. Acesso em: 10 ago. 2016.

JACINTO, Fernanda Maria. O lixo eletrônico e o risco ambiental: a AMMA e os impactos socioambientais oriundos de descarte de produtos de informática na cidade de Goiânia - GO. 2010. Dissertação (Mestrado) - Centro Universitário de Anápolis. UniEvangélica. Mestrado em Sociedade, Tecnologia e Meio Ambiente. Goiânia. 2010.

KASPER, Ângela Cristina. Caracterização e reciclagem de materiais presentes em telefones celulares. 2011. Dissertação (Mestrado) - Universidade Federal do Rio Grande do Sul. Porto Alegre. 2011.

KUNHART, Jorge Luiz. Resíduos eletroeletrônicos: um diagnóstico da cadeia de processamento. Dissertação (Mestrado em Engenharia de Minas, Metalúrgica e de Materiais). Universidade Federal do Rio Grande do Sul. Porto Alegre. 2015.

LAFER, Celso. A reconstrução dos direitos humanos: a contribuição de Hannah Arendt. Estudos Avançados, São Paulo, v. 2, n. 30, 1997.

LEFF, Enrique. Racionalidade Ambiental: a reapropriação social da natureza. Rio 
de Janeiro: Civilização Brasileira, 2006.

LEITE, Paulo Roberto. Logística reversa. São Paulo: Pearson Prentice Hall, 2003.

LEMOS, Patrícia Faga Iglecias. Direito Ambiental: Responsabilidade Civil e Proteção Ao Meio Ambiente. 3. ed. São Paulo: Revista dos Tribunais, 2010.

LENZI, Cristiano Luis. Sociologia Ambiental: Risco e Sustentabilidade na Modernidade. São Paulo: EDUSC, 2010.

LYON, David. Pós-modernidade. São Paulo: Paulus, 1998.

MACHADO, Paulo Affonso Leme. Estudos de Direito Ambiental. São Paulo: Malheiros, 2014. v. 2.

MANSELL, Robin. Imagining the internet. Comunication, inovation, and governance. Oxford University Press. United Kingdom, 2012.

MARIOTTI, Humberto. Complexidade e Sustentabilidade: o Que Se Pode e o Que Não Se Pode Fazer. São Paulo: Atlas, 2013.

MASCARENHAS, Henrique Ribeiro. O setor de eletrodomésticos de linha branca: um diagnóstico e a relação varejo-indústria. Mestrado em Finanças e Economia Empresarial. Faculdade Getúlio Vargas. São Paulo, 2005.

MENDES, Bruna. Lixo eletrônico. Informa ABC. São Bernardo do Campo. 10 de abril de 2013. Disponível em: < http://www.informaabc.com.br/regional/id-27669/ lixo_eletronico >. Acesso em: 31 mar. 2016.

MENDES, Gilmar Ferreira. BRANCO, Paulo Gustavo Gonet. Curso de Direito Constitucional. 7. ed. São Paulo: Saraiva, 2012.

MENDES, Judas Tadeu Grassi. SILVA, Christian Luiz da. Reflexões sobre o desenvolvimento sustentável: agentes e interações sob a ótica multidisciplinar. Petrópolis: Vozes, 2005.

MENDES FILHO, Elson Felix. Redes neurais artificiais. Instituto de Ciências Matemáticas e de Computação. Universidade de São Paulo. 2000. Disponível em: < http:// 
www.icmc.sc.usp.br/>. Acesso em: 01 set. 2016.

MIGUEZ, Eduardo Correia. Logística reversa como solução para o problema do lixo eletrônico benefícios ambientais e financeiros. Rio de Janeiro: Qualitymark. 2010.

MILARÉ, Édis. Direito do ambiente. 4. ed. Rio de Janeiro: Revista dos Tribunais, 2006.

MILTON, Kay. Ecologias: antropologia, cultura y entorno apud WALDMAN, Maurício. Meio ambiente \& antropologia. São Paulo: Editora Senac São Paulo, 2006.

Ministério do Trabalho e Previdência Social. Normas Regulamentadoras. 2015. Disponível em: http://www.mtps.gov.br/seguranca-e-saude-no-trabalho/normatizacao/normas-regulamentadoras. Acesso em 19 de março de 2016.

MIT Institute Archives \& Special Collections. Project Whirlwind. Jul. 2009. Disponível em: https://ibraries.mit.edu/archives/exhibits/project-whirlwind/. Acesso em: 10 nov. 2016.

MOLINARO, Carlos Alberto. Interdição da retrogradação ambiental: reflexões sobre um princípio. In: O PRINCÍPIO da Proibição do Retrocesso Ambiental, Coletânea da Comissão de Meio Ambiente, Defesa do Consumidor e Fiscalização e Controle do Senado Federal. Brasília: Senado Federal, 2012.

MUSARDO, Fernando. Primeiro Computador Digital Eletrônico - ENIAC. 2014. Disponível em: <http://musardos.com/1946/08/31/primeiro-computador-digital -eletronico-eniac/> Acesso em: 20 mar. 2016.

NAKANO, Viviane. AVILA-CAMPOS, Mário Julio. Metais Pesados: um perigo iminente. 2014. Departamento de Microbiologia. Universidade de São Paulo. Disponível em: < http://www.icb.usp.br/> Acesso em: 10 mar. 2016.

NETO, Nagib Anderáos. Os livros guardados que vivem. 2003. Disponível em: http://www.nagibanderaos.com.br/. Acesso em 22 de fevereiro de 2016.

NUSDEO, Ana Maria de Oliveira. Pagamento Por Serviços Ambientais: sustentabilidade e disciplina jurídica. São Paulo: Atlas, 2012. 
Organização das Nações Unidas. Brasil produziu 1,4 milhão de toneladas de resíduos eletrônicos em 2014, afirma novo relatório da ONU. 20 de maio de 2015. Disponível em: < https://nacoesunidas.org/brasil-produziu-14-milhao-de-toneladasde-residuos-eletronicos-em-2014-afirma-novo-relatorio-da-onu/> Acesso em: 10 mar. 2016.

Organização das Nações Unidas. Declaração de Estolcomo sobre o ambiente humano. Junho de 1972. Disponível em: < http://www.silex.com.br/leis/normas/ estocolmo.htm >. Acesso em: 26 mar. 2016.

Organização das Nações Unidas. ONU prevê que mundo terá 50 milhões de toneladas de lixo eletrônico em 2017. Disponível em: < https://nacoesunidas.org/ onu-preve-que-mundo-tera-50-milhoes-de-toneladas-de-lixo-eletronico-em-2017/>. Acesso em: 10 mar. 2016.

PESSANHA, Fabiano. FERRAZ, Hugo. Como comprar ações de empresas dos EUA, como Apple e Google? Revista Exame, 19 de março de 2015. Disponível em: $<$ http://exame.abril.com.br/seu-dinheiro/noticias/como-comprar-acoes-de-empresas-dos-eua-como-apple-e-google > . Acesso em: 21 mar. 2016.

PIOVESAN, Flávia. Temas de direitos humanos. 7. ed. São Paulo: Saraiva, 2014.

PLATONOW, Vladimir. Brasil apoia medidas da ONU para banir substâncias químicas poluentes. Agência Brasil. Empresa Brasil de Comunicação. 26 ago 2010. Disponível em: < http://memoria.ebc.com.br/agenciabrasil/noticia/2010-08-26/brasil -apoia-medidas-da-onu-para-banir-substancias-quimicas-poluentes $>$. Acesso em: 21 nov. 2016.

POMBO, Olga. The Abacus. 2010. Mini Web Educação. Disponível em: < http:// www.miniweb.com.br/ciencias/artigos/abaco_historia.html $>$. Acesso em: 20 de março de 2016.

Polo de Reciclagem de Eletroeletrônicos. PREEL. Universidade Estadual de São Paulo. 2010. Disponível em: < http://www.feg.unesp.br/ preel/first.html > . Acesso em: 02 set. 2016.

PORTAL BRASIL. Meio ambiente. Desastre ambiental. Entenda o acidente de Mariana e suas consequências para o meio ambiente. 23 dez. 2015. Disponível em: 
$<$ http://www.brasil.gov.br/meio-ambiente/2015/12/entenda-o-acidente-de-mariana -e-suas-consequencias-para-o-meio-ambiente > . Acesso em: 19 jan. 2016.

PORTILHO, Fátima. Sustentabilidade ambiental, consumo e cidadania. São Paulo: Cortez, 2005.

Rede de aplicativos de android. Melhores aplicativos de comunicação para android. 17 de janeiro de 2013. Disponível em: < http://redeaplicativosdeandroid. blogspot.com.br/2013/01/melhores-aplicativos-de-comunicacao.html>. Acesso em: 13 mar. 2016.

REIS, Auristela Oliveira. Os direitos humanos, o direito penal e o direito internacional. 2003. Dissertação (Mestrado)-Universidade Federal da Bahia. Bahia, 2003.

REZENDE, Denise Alcides. Planejamento de sistemas de informação e informática: guia prático para planejar a tecnologia da informação integrada ao planejamento estratégico das organizações. São Paulo: Atlas, 2003.

RIBEIRO, Ricardo Lodi; CARLI, Ana Alice de; COSTA, Leonardo Andrade de. Tributação e sustentabilidade ambiental. São Paulo: Editora FGV, 2015.

ROCHA, Leonel Severo. DUARTE, Carlos Francisco. Direito ambiental e autopoiese. Curitiba: Juruá, 2012.

RODRIGUES, Fabíola. BAENINGER, Rosana. Dinâmica da população e políticas sociais. In. População e Cidades: subsídios para o planejamento e para as políticas sociais. Campinas: Núcleo de Estudos de População-Nepo/Unicamp; Brasília: UNFPA, 2010.

SANTOS, Boaventura de Sousa. Democratizar a democracia: os caminhos da democracia participativa. Rio de Janeiro: Civilização Brasileira, 2002.

SANTOS JÚNIOR, Antônio dos. Meio ambiente como direito fundamental. 2007. Dissertação (Mestrado em Direito). Pontifícia Universidade Católica do Paraná. Curitiba, 2007.

SÃO PAULO. Lei estadual no $\mathbf{.}$ 13.576, de 06 de julho de 2009: Institui normas e pro- 
cedimentos para a reciclagem, gerenciamento e destinação final de lixo tecnológico.

SAP. Sistema Ambiental Paulista. Governo do Estado de São Paulo. Cetesb multa Ultracargo em R\$ 22,5 milhões pelo incêndio em Santos. 14 abril 2015. Disponível em: <http://www.ambiente.sp.gov.br/2015/04/15/cetesb-multa-ultracargo-em-maisde-22-milhoes-pelo-incendio-no-terminal-da-alemoa/ > . Acesso em: 20 jan. 2017.

SARLET, Ingo Wolfgang. A eficácia dos direitos fundamentais. Porto Alegre: Livraria do Advogado, 1998.

SARLET, Ingo Wolfgang. Dignidade da pessoa humana e direitos fundamentais na constituição federal de 1988. 7. ed. Porto Alegre: Livraria do Advogado, 2009.

SILVA, Geraldo E. do Nascimento. Direito Ambiental Internacional. 2. ed.Rio de Janeiro: Thex, 2002.

SILVA, José Afonso da. Direito ambiental constitucional. São Paulo: Malheiros, 2013.

SILVA, Solange Teles da. O direito ambiental internacional. São Paulo: Del Rey, 2010.

SIMIONI, Rafael Lazzarotto. Direito ambiental e sustentabilidade. Curitiba: Juruá. 2006.

SIRVINSKAS, Luís Paulo. Manual de direito ambiental. 8. ed. São Paulo: Saraiva, 2010.

SMANIO, Gianpaolo Poggio; BERTOLIN, Patrícia Tuma Martins. (Org.). O direito e as políticas públicas no Brasil. São Paulo: Atlas, 2013.

SOUSA, Sérgio. Tecnologias de informação. Rio de Janeiro: Ed. Brasport, 2000.

SLATER, Don. Cultura do Consumo e Modernidade. São Paulo: Nobel, 2002.

Sustainable Innovation and Technology Transfer Industrial Sector Studies. Recycling -from e-waste to resources. Julho de 2009. Disponível em: < http://www.unep. org/pdf/Recycling_From_e-waste_to_resources.pdf $>$. Acesso em: 18 mar. 2016. 
TASCHNER, Gisela. Cultura do consumo, cidadania e movimentos sociais. Revista Ciências Sociais Unisinos, jan/abril 2010. Disponível em: <http://revistas.unisinos.br/index.php/ciencias_sociais/article/viewFile/170/40>. Acesso em: 21 nov. 2016.

UFC. Universidade Federal do Ceará. Estudantes da UFC desenvolvem aplicativo que lista pontos adequados para descarte de materiais. 01 jun.2016. Disponível em: < http://www.ufc.br/noticias/noticias-de-2016/8345-estudantes-da-ufc-desenvolvem-aplicativo-que-lista-pontos-adequados-para-descarte-de-materiais $>$. Acesso em: 20 jan. 2017.

UNESCO. Vamos cuidar do Brasil: conceitos e práticas em educação ambiental na escola. Brasília: Ministério da Educação, Coordenação Geral de Educação Ambiental: Ministério do Meio Ambiente, Departamento de Educação Ambiental, 2007. p.15. Disponível em: <http://portal.mec.gov.br/secad/arquivos/pdf/educacaoambiental/ educacaoambiental_naescola.pdf $>$. Acesso em: 10 nov. 2016.

UniCesumar. Assessoria de Imprensa. Cesumar coleta mais de 2,5 toneladas de lixo eletrônico. 08 de junho de 2012. Disponível em: <http://www.unicesumar. edu.br/imprensa/noticia.php?idNoticia=1991> . Acesso em: 30 mar. 2016.

UNIVERSIDADE FEDERAL DE SÃO PAULO. Projeto Ecounifesp. 2010. Disponível em: < http://dgi.unifesp.br/ecounifesp> Acesso em: 31 mar. 2016.

VARELLA, Marcelo Dias. Direito internacional econômico ambiental. São Paulo: Del Rey, 2004.

WASTE Electrical and Electronic Equipment - WEEE. 2015. Disponível em: <ec.europa.eu/environment/waste/weee/index_en.htm > . Acesso em: 11 mar. 2016.

Recebido em: 23 de novembro de 2016 Aceito em: 19 de junbo de 2017 